\title{
African Challenges to the International Criminal Court: An Example of Populism?
}

\author{
Renée Nicole Souris
}

\begin{abstract}
Recent global efforts of the United States and England to withdraw from international institutions, along with recent challenges to human rights courts from Poland and Hungary, have been described as part of a growing global populist backlash against the liberal international order. Several scholars have even identified the recent threat of mass withdrawal of African states from the International Criminal Court (ICC) as part of this global populist backlash. Are the African challenges to the ICC part of a global populist movement developing in Africa? More fundamentally, how are the African challenges to the ICC examples of populism, if at all? In this paper, I show that, while there is considerable overlap between the strategies used by particular African leaders to challenge the ICC and those typically considered populist, as well as a discernible thin populist ideology to sustain them, there is insufficient evidence of a larger anti-ICC populist movement in Africa. Although Africa is not as united against the ICC as the populist narrative suggests, the recent challenges to the Court from Africa pose a significant challenge to the Court, as the institution is still in the early stages of building its legitimacy.
\end{abstract}

\section{Introduction}

Recent global efforts of the United States and England to withdraw from international institutions, along with recent challenges to human rights courts from Poland and Hungary, have been described as part of a growing global populist backlash against the liberal international order. Several scholars have even identified the recent threat of mass withdrawal of African states from the International Criminal Court (ICC) as part of this global populist backlash (Voeten 2019; Helfer 2018; Posner 2017). Are the African challenges to the ICC part of a growing global backlash against liberal internationalism? More fundamentally, how are the African

R. N. Souris $(\bowtie)$

Florida Institute of Technology, Melbourne, FL, USA

e-mail: rsourissmith@ fit.edu 
challenges to the ICC examples of populism, if at all? My aim in this paper is to answer the latter of these questions.

Populism has recently become a subject of renewed scholarly interest, and considerable debate exists about the proper definition and application of the concept. The term populism has been used to describe a movement, a kind of ideology, and a kind of strategy or discourse used by political leaders. This section lays out some current debates about populism, introduces a definition of populism that is mainstream in the literature, and describes particular strategies used by populist leaders.

Ernesto Laclau's (1977, 2012 reprint edition) influential account of populism maintains that populism is more about form than substance. The broad ideology upon which populism rests is that the will of the people should rule, which makes democracy the typical home of populism. Beyond appealing to the people, Laclau argues that populism is not associated with any more particular political ideology. In his more recent work, Laclau (2005) identifies three preconditions for the rise of a populist movement: first, 'a vague feeling of generalized dissatisfaction,' secondly, a 'qualitative jump' that crystallizes into a 'discourse that divides society into two camps: the people and those in power,' and thirdly, the emergence of an 'empty signifier' that represents the unsatisfied demands of the people as a totality. Generally speaking, Laclau argues that populism can be a particularly positive force in a democracy, insofar as it livens the populace and can uproot an oppressive political system.

Other, more contemporary scholars have been particularly critical of populism, especially with regard to populism's impact on democratic values and practices. Cas Mudde (2015b) defines populism as 'a thin-centered ideology that considers society to be ultimately separated into two homogenous and antagonistic groups, 'the pure people' versus 'the corrupt elite,' and which argues that politics should be an expression of the volonté générale (general will) of the people.' This definition figures prominently into contemporary work on populism, and enjoys support even among those who regard populism as a strategy rather than a sort of ideology (Posner 2017; Friedman 2017; Resnick 2017; de la Torre 2015). Mudde (2015a) generally agrees with Laclau that populism is not about substance, but about form. Unlike Laclau, however, Mudde insists that populism is a particularly problematic form of political expression in a democracy, insofar as it embraces a form of moral monism that denies the existence of divisions in society, and rejects the legitimacy of opposition. Similarly, Jan-Werner Müller (2016) argues that populists claim a moral monopoly on defining who is part of 'the people,' which is exclusionary and harmful to democracy.

Mudde (2015a) explains that populists reject compromise, insofar as compromise is seen as corrupting the pure will of the people. Instead, populist leaders embrace a single narrative of the will of the people, which populist leaders take as their moral and political mandate. Mudde thus further argues that populism is anti-pluralist and, thus, necessarily anti-liberal-democratic, insofar as pluralism is necessary for liberal democracy (2015b, p. 433). This is true, for Mudde, of both right- and left-wing variations of populism. William Galston (2018) shares the view that populism is exclusionary, but he denies the existence of left-wing populism. For Mudde, 
left-wing variations of populism are typically less exclusionary than right-wing variations, but both are exclusionary, because they reject opposing views as illegitimate.

Some scholars have added that when populists challenge the 'elites,' they do so either as outsiders on behalf of common people, or as insiders who claim a mandate from them (Posner 2017, p. 2; Resnick 2017). Right-wing populists in the US and Europe today identify a liberal, cosmopolitan elite as the corrupt enemy of the pure people, who are identified in nationalistic terms. Left-wing populists, by contrast, typically claim to represent the will of the economically oppressed people who are united against a greedy, often domestic, elite who controls the system.

In addition to carving society into two separate and homogenous groups, with the pure people on one side, and the corrupt elite on the other, some argue that populists also challenge institutions that constrain their ability to translate the voice of the people into legal and political realities. Robert Jansen (2015) explains that populists typically try to bypass existing institutions, and Kenneth Roberts (2015) observes that populism grows more readily where institutions are already weak or discredited, or where people feel alienated by existing institutions. Furthermore, some populist leaders rely on 'political theology,' by using religious images and essentialist narratives of the people, to bypass institutions (de la Torre 2015; Arato 2015).

A further common theme is that populists typically use catchy slogans, and often direct language to appeal to the masses (Posner 2017; Friedman 2017; Norris and Inglehart 2019). In the US, we see this, for example, in Trump's slogan to 'Make America Great Again,' and in the promise of the Occupy Movement to free the American poor and diminishing middle class from the economic oppression of the 'One Percent.' De la Torre (2015) and Resnick (2015) add that populists also typically use symbolic or cultural performances to appeal to common people.

\section{African Challenges to the ICC}

Before we can evaluate in what sense, if any, the African challenges to the International Criminal Court (ICC) are examples of populism, we need to consider what those challenges are. I focus primarily on the anti-ICC efforts of three African heads of state-former President al Bashir of Sudan, President Kenyatta of Kenya, and former President Zuma of South Africa-with occasional reference to other African political leaders.

It is worth noting that African states played a pivotal role in bringing the ICC into being. The first country in the world to ratify the Rome Statute, which is the founding and governing document of the Court, was Senegal, an African state, in 1999. The Democratic Republic of the Congo (DRC) was the 60th state to ratify the Statute, in 2002, thereby allowing it to enter into force. In 2004, the ICC had its first case-a self-referral from the Democratic Republic of the Congo (DRC) - to investigate alleged Rome Statute crimes of Congolese rebel leaders in the context of an ongoing armed conflict. Soon after, Uganda and the Central African Republic (CAR) 
followed with self-referrals of rebel leaders in their respective states. These selfreferrals provided a 'soft landing' for the ICC, insofar as the two other referral mechanisms are considered more controversial (Kuwali 2018). The two other referral mechanisms are: an independent referral by the ICC's Office of the Prosecutor (OTP) (which was later carried out in Kenya, Cote d'Ivoire, Georgia, and Burundi) and a referral by the United Nations (UN) Security Council (used to refer cases in Sudan and Libya). As of November 2018, all but one of the ICC's eleven situations in its docket investigates individuals involved in conflicts in Africa, which has raised concerns that the ICC is inappropriately targeting Africa.

Aside from the apparent 'Afrocentrism' of ICC investigations, three specific actions undertaken by the Court's first Prosecutor, Luis Moreno Ocampo, diminished African support for the Court over the last decade. The first is when the OTP issued an arrest warrant for Sudanese President al Bashir for alleged genocide in Darfur in 2009 pursuant to a referral by the UN Security Council. This was controversial for several reasons. Not only is Sudan not a member of the ICC, but also this was the first ICC arrest warrant issued for a sitting president, as well as the first ICC referral through the UN Security Council. This ushered in criticism from certain African leaders, especially from al Bashir himself. In a 2009 interview, al Bashir denounced the ICC as a 'tool to terrorize countries that the West thinks are disobedient' (Dealey 2009).

Using the pulpit of the African Union (AU), an intergovernmental organization consisting of all 54 African countries organized to promote unity and solidarity in Africa, al Bashir claimed head of state immunity under customary international law. With his own people, al Bashir used public spectacles to maintain support. Al Bashir often danced on stage, while waving a stick and speaking in the common tongue of his people, while he denounced his enemies as 'insects' (Fletcher 2012). The arrest warrant for al Bashir strained relations between the ICC and the AU, so much so that leaders of the AU petitioned the OTP to rescind the arrest warrant against al Bashir, and when the ICC did not, the AU called for non-cooperation with the Court (Hobbs 2015, p. 7). Muammar Gaddafi, who was the acting Chairperson of the AU at the time, as well as the President of Libya, criticized the ICC's action, calling it 'an attempt by [the West] to re-colonise their former colonies' (Vilmer 2016, p. 1321, citing BBC 2009).

The second action that ushered in criticism from Africa is when former Prosecutor Ocampo initiated an investigation in 2010 into Kenyan politicians, Uhuru Kenyatta and William Ruto, for violence that erupted in Kenya after the Presidential Election of December 27, 2007, which caused 1200 deaths and 300,000 displaced persons (Hobbs 2015). Kenyatta at first demonstrated a willingness to cooperate with the ICC's investigation into the post-election violence for which he was allegedly responsible, but he soon became uncooperative (Hobbs 2015). ICC arrest warrants were issued for six Kenyan politicians, including Kenyatta and Ruto, who were collectively labeled the 'Ocampo Six.' In response, Kenyatta and his supporters sought to mobilize the Kenyan masses against the ICC. Moreover, he sought to do this while campaigning for President in the next Kenyan Presidential Election. 
Specifically, Kenyatta and Ruto appealed to Kenyans who were previously opposed on ethnic grounds, and united them against a common enemy: the ICC (Maupeu 2013). They led prayer tours through Kenya, which Hervé Maupeu describes as a sort of 'pentacostalization of political life.' Through pentacostal rituals, Kenyatta and Ruto spread the narrative that God blessed them in their efforts to bring peace to Kenya and denounced those guilty of causing the misfortunes of Kenyans, namely, Westerners (Maupeu 2013).

In 2013, Kenyatta and Ruto were elected President and Deputy President, respectively. At the 2013 Anniversary Summit of the AU, President Kenyatta used his new position of authority to criticize the Court. Like al Bashir, he appealed to head of state immunity under customary international law to argue the ICC had no jurisdiction over him (even though Kenya, unlike Sudan, ratified the Rome Statute, and Article 27 of the Statute declares official capacity irrelevant to whether an individual can be prosecuted at the Court.) Kenyatta called for mass withdrawal of African states from the ICC, asserting that ICC investigations are nothing but 'race hunting' in Africa (Vilmer 2016, p. 1322). A similar view was expressed by a former Gambian Information Minister, who asserted that the acronym 'ICC' stands for the 'International Caucasian Court,' and who accused the Court with persecuting and humiliating people of color (Hersher 2016). Ultimately, after key witnesses in the Kenyatta case disappeared or were killed, the ICC dropped the charges against Kenyatta for lack of sufficient evidence.

The third event that diminished African support for the ICC arose when the ICC filed a formal complaint against South Africa for welcoming al Bashir into South Africa for a Summit of the AU in 2015, rather than arresting him, pursuant to the ICC arrest warrant issued against him in 2009. South African President Zuma argued he had a duty, recognized by Article 98 of the Rome Statute, to provide diplomatic immunity to senior foreign officials who visited South Africa, and if challenged by the ICC, President Zuma threatened to withdraw from the Court. When the ICC issued a complaint against South Africa, South Africa notified the UN Security Council that it was withdrawing from the ICC in October 2016. While President Zuma did not politically campaign against the ICC (like Kenyatta) or accuse the ICC of inappropriately targeting Africa (like Kenyatta and al Bashir), Zuma's refusal to cooperate with the Court was a meaningful challenge to the Court's legitimacy. Not only was the Court already challenged by two other powerful African heads of state, Kenyatta and al Bashir, but also South Africa was an early advocate of the Court during the Rome Conference, as a member of the LikeMinded Group, which was pivotal in drafting and passing the Rome Statute. Thus, South Africa's refusal to cooperate with the Court exposed the weakness of the new institution, relative to established state power. In the same month as South Africa's public statement of withdrawal, two other African states-Burundi and The Gambia-also notified the UN Security Council of their intention to withdraw from the Court (Kuwali 2018). Some argued that Kenya was soon to follow. 


\section{Are the African Challenges to the ICC an Example of Populism?}

The strategies of Presidents al Bashir, Kenyatta, and Zuma are examples of particular kinds of political leaders, namely what Clarke (2009) calls, 'Big Men Presidents,' who anchor their political power in their personal rule. But are they also populists? Interestingly, recent literature on contemporary African populism does not point to the anti-ICC efforts described above as examples of African populism, though both Presidents Kenyatta and Zuma are identified as populist leaders in this literature (Cheeseman and Larmer 2015; Resnick 2015; Resnick 2017). Other scholars identify the African challenges to the ICC as part of the global populist backlash against liberal internationalism, but do not support this claim with concrete examples from Africa (Voeten 2019; Helfer 2018; Posner 2017). In a 2017 working paper, Helfer and Showalter (2017) offer a systematic analysis of Kenya's integrated backlash strategy against the ICC, but they do not describe this backlash as a distinctly populist one. In this section, I directly examine whether the anti-ICC strategies of the African leaders described in the previous section fit the description of populism laid out in Section 1.

There are clear similarities between the strategies typically used by populist leaders and the strategies employed by the African leaders described above. For instance, President al Bashir's tactic of speaking in the common tongue of his people when he denounces his enemies as 'insects' is a direct use of language that is meant to appeal to the masses, which is common of the populist form (Posner 2017; Friedman 2017). Further, when al Bashir dances on the stage and waves a stick when he addresses his people, he is appealing to the kinds of cultural and symbolic performances that de la Torre (2015) and Resnick (2015) link to populist leaders. Arguably, Kenyatta's pentacostal missions are examples of political theology used by populists, as described by Arato (2015).

Roberts (2015) observed that populism grows more readily where institutions are already weak or discredited, which might not seem to apply to Kenya or South Africa, insofar as these states have some of the stronger democratic institutions in Africa. However, Kagwanja (2009) notes that, around the 2007 Presidential Election, Kenya was ripe for unrest due to problems of poverty, inequality, and corruption, which gave rise to ethno-nationalist sentiment in Kenya. In postApartheid South Africa, a feeling of alienation from democratic institutions continued to exist for many, which provides fertile soil for the growth of populism. What is more, Jansen's (2015) point that populists try to bypass existing institutions is apparent in the strategies of Kenyatta and Zuma, both of whom tried to circumvent legal process at the ICC.

Beyond these rather loosely connected populist strategies, do the African political leaders who challenge the ICC appeal to something deeper, perhaps, that is, to a shared ideology? To recall, Mudde's influential definition of populism holds that populism is 'a thin-centered ideology that considers society to be ultimately separated into two homogenous and antagonistic groups, 'the pure people' versus 'the 
corrupt elite' and which argues that politics should be an expression of the volonté générale (general will) of the people.' Assuming the African anti-ICC efforts are sustained by a populist ideology, let us then answer three questions to make sense of it: who are the pure people, who are the corrupt elite, and do the African leaders who challenge the ICC represent the voice or will of people, who have until now remained a silent majority?

Let us consider President Kenyatta's efforts to unite Kenyans who were previously divided on ethnic grounds, and to pit them against the ICC. This appears to do what Mudde's definition says populism does, carve out two homogenous and antagonist groups: the ICC and Kenyans. This would suggest that President Kenyatta is advancing a sort of right-wing populism, given the nationalistic construct of the pure Kenyan people. Maupeu (2013) explains, however, that when Kenyatta challenges the ICC, he treats the Court as a stand-in for something broader, namely the West. That the ICC is a stand-in for the West is supported by claims made by other Africa leaders, former President al Bashir and former President Gaddafi, who accuse the ICC of being a neo-colonial tool used by the West to carry out regime change through the guise of law. The West, however, is not part of the society of any state, but is part of global society. Thus, if Kenyatta's challenges to the ICC rely on, and express, a populist antagonism, then it seem to be between the West that the ICC embodies, as the corrupt global elite, and the silent majority of Kenyans as the pure people.

When Kenyatta asserts that the ICC is waging a 'race hunting' campaign, however, he appeals beyond Kenyans, to Africans as a people, and even to blacks as a race. A former Gambian Information Minister does something similar when he asserts that the acronym 'ICC' stands for the 'International Caucasian Court,' and when he claims that the ICC operates by persecuting and humiliating people of color. These accusations about the racial bias of the Court suggest that the two groups in the populist antagonism are not Kenyans, or Gambians, or people of any particular African state, and the ICC/West, but rather Africans and the ICC/West, or perhaps more fundamentally, blacks and whites.

Clarke $(2009,2015)$ has written extensively on the idea that the ICC represents whiteness and reproduces images of blackness as either warlord, or as victim in need of saving by whites. She argues that the ICC operates problematically on the basis of Western, liberal ideas of individual criminal responsibility, which ignore the longstanding material causes of violence in Africa (2009, 6-8). Moreover, Clarke (2016) argues that there is inherent racial bias built into the Rome Statute's understanding of international crime, insofar as the kind of violence that is typically carried out by Western states through colonialism and domination is not recognized as criminal, whereas the violence that is more typically carried out in African states is identified as criminal. Mills (2008) has advanced similar arguments about the inherent racial bias and injustice of liberal ideas and practices. This suggests a deep-rooted racial antagonism might be behind the populist antagonism underlying the African challenges to the ICC.

If underlying the challenges to the ICC from Kenyatta and others is a challenge to the West, and what it represents, from Africa as a whole, then we should expect to 
see African state support, and popular African support, for withdrawal. Beyond antiICC populist strategies, and the thin ideology that appears to sustain them, is there sufficient evidence of an anti-ICC populist movement in Africa? One might ask why it matters whether there is an anti-ICC populist movement in Africa. To this, I respond as follows. When a leader who truly embodies the will of a silent majority comes into power, it is reasonable to expect this majority to use the political leverage provided by the leader to translate their will into legal and political reality. If there is a populist antagonism between the pure people of Africa and the Western, liberal elite of the ICC, then we should expect to see this will instantiate into a real African withdrawal movement when the opportunity for exit arises.

Vilmer (2016), however, questions the notion that the silent majority of Africans is united against the ICC:

Heads of state should not be confused with their populations: the hostility to the ICC comes not from 'Africa' but from certain African leaders, simply out of fear of being next on the list. They play on anti-colonial populism, which is often strongly echoed in the African press. The anti-ICC propaganda has been entirely created by a handful of heads of states seeking to escape its reach. However, their discourse can be persuasive, and so it remains unclear to what extent these perceptions are genuinely shared among African populations (Vilmer 2016, p. 1337).

Vilmer suggests that African leaders who challenge the Court exploit the anticolonial concerns of African people in order to protect themselves from the Court's reach. In what follows, I offer evidence to support Vilmer's suspicion, to question the idea that Africa is united against the ICC, and to dispel the idea that there is a general anti-ICC populist movement in Africa. A movement has a sort of temporality to it, so I will address this issue by considering evidence before, during, and after the challenges to the Court were advanced by Kenyatta and others.

Before tensions developed between the ICC and certain African leaders, let us recall how the ICC acquired jurisdiction over several of its cases. The first three cases to come to the ICC were through state self-referral in the DRC, Uganda, and CAR. The two cases that came to the ICC via the Prosecutor's propio motu powers of selfinitiation-Kenyan and Mali-were done so with the authority of the respective governments. In Sudan and Libya-the two cases referred to the ICC via UN Security Council vote-all three African states on the Council (which has a total of 15 members) voted in favor of referring a fellow African state. Specifically, the DRC, Benin, and Tanzania voted to refer Sudan, and South Africa, Gabon, and Nigeria voted to refer Libya (Steinberg 2016).

During the onset of African challenges to the Court, the ICC still continued to develop support with African states. Two overall responses from Africa are particularly noteworthy in challenging the idea that Africa is united against the Court: first, the leadership roles that African states are taking to affirm or re-affirm their commitment to the ICC despite the challenges from other states; and, secondly, the efforts of African courts and other legal bodies to challenge the withdrawal threats through rule of law.

To elaborate on each of these, consider, first, that while Presidents Kenyatta, al Bashir, Zuma, and Gaddafi used their leadership positions in the AU to spread the 
narrative that Africa was united against the Court in calling for collective withdrawal, new African states ratified the Rome Statute and members of the ICC publicly reaffirmed their commitment to the Court. While the AU's aim is to create and represent African solidarity, it cannot impose collective withdrawal on African states. Nor does the AU actually represent the position of each individual African state with regard to the ICC. New African states that have signed and ratified the Rome Statute even after the AU leadership opposed the Court include Seychelles in 2010, Tunisia and Cape Verde in 2011, and Cote d'Ivoire in 2013 (Vilmer 2016, p. 1322).

In response to withdrawal threats from other African states, Zambian President Edgar Lungu, polled his people to ask whether they wanted Zambia to withdrawal from the ICC. An overwhelming $93.3 \%$ of Zambians who participated voted in favor of Zambia remaining in the ICC (Mavhinga and Stagno Ugarte 2017). Moreover, Botswana not only is a strong supporter of the Court, and challenges anti-ICC claims made by the AU, but also even declares it would arrest Al-Bashir if given an opportunity (Mills and Bloomfield 2017, p. 121). In July 2016, Botswana was joined by Nigeria, Senegal, Tunisia, Cote d'Ivoire, and Algeria in rejecting calls from the AU's leadership for mass withdrawal, such that the issue did not even make it onto the agenda during the annual AU Summit (Mills and Bloomfield 2017).

Secondly, some of the greatest challenges to the withdrawal momentum came from states whose leaders mounted the opposition to the Court, including, Kenya, South Africa, and The Gambia. In Kenya, the post-election crimes were first brought to the attention of the ICC when the Kenyan Waki Commission, which was sponsored by the AU, shared with the ICC its dissatisfaction with how the Kenyan Government was responding to the Commission's judgment that a special tribunal be set up to investigate crimes against humanity in connection with the violence. Originally, Parliamentarians from both sides of the partisan divide-the Orange Democratic Movement and the Party of National Unity - united under the slogan 'Don't be vague; let's go to the Hague' and sought international legal accountability for the post-election violence (Clarke 2015, p. 599).

Once Kenyatta was elected President, he declared an intention to withdraw from the ICC, but as of 2018, Kenyatta still has not brought the decision into effect by notifying UN Secretary General, as required by Article 127 of Rome Statute. According to a 2015 Afrobarometer survey, a majority of Kenyans reported their support for ICC prosecutions of Kenyan political figures, the belief that the Court is an important tool toward achieving accountability in the country, and a rejection of withdraw from the Court (Lekalake and Buchanan-Clarke 2015). This arguably would make withdrawal a bad political move for Kenyatta. In February 2018, African newspapers reported that the outgoing Attorney General of Kenya, Githu Muigai, who left office on good terms with Kenyatta, reaffirmed Kenya's commitment to the ICC, noting that Kenya has no intention of withdrawing from the Court, and welcomes the ideals of the Rome Statute and partnerships that will allow Kenya to address problems plaguing the state (Ndunda February 2018; Odongo February 2018). 
Similarly, a withdrawal from the Court by South Africa has not been officially pursued, despite threats of withdrawal from President Zuma (Gumede 2019). In what some call a triumph of the rule of law, the Supreme Court of South Africa blocked Zuma from using executive power to withdraw from the ICC, judging withdrawal to be in violation of South Africa's constitutional obligations (Vilmer 2016). Because the South African Parliament voted to ratify the Rome Statute, the Court held that Parliament must vote on withdrawal if South Africa wishes to leave the ICC. Currently, in South Africa, the recent resignation of President Zuma, and his prosecution in national courts for corruption charges, has enervated the discussion of withdrawal of momentum. Moreover, Gambia threatened to withdraw from the Court over the last decade, but the country has since elected a new president, and officially reversed its position on the ICC, now stating the intent to remain with the Court.

How do we make sense of the withdrawal threats in light of the reality that only one African state has actually withdrawn from the Court? Bosco (2014) suggests that the threat of withdrawal is actually an effort to control the ICC, rather than to marginalize or undermine it. This is supported by recent empirical work by Franziska Boehme (2018) which shows that most African leaders use anti-ICC discourse as a tool of 'voice' to express internal dissatisfaction with the Court, rather than to express a real intention to leave the institution. Particularly, African states used voice to express criticism of the politicization of the ICC, of the UN Security Council's referral of al Bashir to the Court, and of the ICC's past refusal to fulfill deferral requests for Sudan and Kenya (Boehme 2018, p. 433). Despite this criticism, Boehme concludes that most African states express the intention to remain with the Court rather than to leave it. In fact, he found that African states have made more public statements at the UN expressing loyalty to the Court in 2017 than in 2007. This shows that, while African leaders who led the charge against the ICC used populist strategies and ideology to present a picture of Africa united against the Court, this is a deceptively false narrative that fails to capture continued African support for the institution.

\section{Conclusion}

In October 2016, the mass exodus of African states from the ICC appeared to be on the horizon as three states-South Africa, The Gambia, and Burundi-notified the UN Security Council of their intent to withdraw from the ICC. As of October 2019, however, the only African state to withdraw from the ICC is Burundi, where the withdrawal process was initiated after the ICC began investigating crimes against humanity that were allegedly carried out by state agents against the Burundi civilian population. Examining the use of populist strategies and ideology by particular African leaders to challenge the ICC allows us to acquire a deeper understanding of some of the dangers with populist politics. 
True to Mudde's paradigm of populism, the African leaders who use populist strategies to challenge the ICC also call Africans who support the ICC 'neo-colonial puppets' (Achaleke Taku 2016). By derogatorily labeling African states that support the ICC neo-colonial puppets, these leaders thereby reject opposing views as illegitimate. For them, there is no compromise or plurality of positions to be considered regarding the ICC. This problematically frustrates the possibility for real deliberation on the serious issues at stake in the anti-ICC African narrative to take place. To strengthen the democratic foundations of relatively new democracies in Africa, African political leaders should provide their peoples with the space to deliberate on the justice sought by the ICC that addresses the neocolonial concerns of Africans, rather than simply exploiting those concerns.

A further concern is that, in rejecting opposition as illegitimate, populist leaders claim to represent the will of the people as a whole, and rely on totalizing narratives to do this, which can snowball into more public support for platforms than previously existed. Rather than voicing the will of an existing majority, populist leaders may be able to construct a new majority, if those who oppose them are not given a genuine opportunity to speak out against their political views. This is particularly dangerous when leaders claim to represent the will of the people and work to undermine institutions that were designed to protect people from oppressive governments.

Moreover, insofar as it is typical for populist leaders to resort to threats, it exposes another concern with populist politics. The record shows that anti-ICC African leaders used threats to withdrawal from the ICC to voice criticism from within the Court, rather than to express the concrete intention to leave it. The use of threat as a political strategy is problematic because it does not encourage compromise or consensus, but instead operates on deceptively simple false narratives and presents single-sided solutions that fail to capture the nuance of complex political issues.

Ultimately, the populist strategies and ideology used by particular African leaders to challenge the ICC do not represent the full story. Africa has a far more complex relationship with the Court than the populist narrative suggests, and democratic deliberation on the nature of this relationship is needed to remedy the deceptively simple false narrative that Africa is united in opposition against the Court. Nonetheless, while Africa is not united against the Court, the anti-ICC populist narrative constructed by particular African political leaders has weakened the sociological legitimacy of the institution, and because the ICC's normative legitimacy depends, in part, on its sociological legitimacy, these challenges have challenged the Court's normative legitimacy as well. For the Court to demonstrate its normative legitimacy, it must take seriously the accusations advanced against it by particular African leaders. This creates a need for the ICC to shape its institutional character and identity in Africa, and will hopefully provide African peoples the opportunities to 
voice their concerns in a way that promotes human rights and accountability on the continent. ${ }^{1}$

\section{References}

Achaleke Taku C (2016) International politics and policy considerations for the inappropriate targeting of Africa by the ICC OTP. In: Steinberg RH (ed) Contemporary issues facing the International Criminal Court. Brill Nijhoff, Leiden, pp 338-350

Arato A (2015) Political theology and populism. In: de la Torre C (ed) The promise and perils of populism: global perspectives. University Press of Kentucky, Lexington, pp 31-58

BBC (2009) Sudan leader in Qatar for summit. BBC, March 29

Boehme F (2018) Exit, voice and loyalty: state rhetoric about the International Criminal Court. Int J Hum Rights 22(3):420-445

Bosco D (2014) Rough Justice: the International Criminal Court in a world of power politics. Oxford University Press, Oxford

Cheeseman N, Larmer M (2015) Ethnopopulism in Africa: opposition mobilization in diverse and unequal societies. Democratization 22(1):22-50

Clarke KM (2009) Fictions of justice: the International Criminal Court and the challenge of legal pluralism in Sub-Saharan Africa. Cambridge University Press, New York

Clarke KM (2015) Refiguring the perpetrator: culpability, history, and international criminal law's impunity gap. Int J Hum Rights 19(5):592-614

Clarke KM (2016) Why Africa? In: Steinberg RH (ed) Contemporary issues facing the International Criminal Court. Brill Nijhoff, Leiden, pp 326-332

De la Torre C (2015) Introduction: power to the people? Populism, insurrections, democratization. In: de la Torre C (ed) The promise and perils of populism: global perspectives. University Press of Kentucky, Lexington, pp 1-28

Dealey S (2009) Omar al-Bashir: Sudan's Wanted Man. TIME, August 13

Fletcher P (2012) NEWSMAKER- Bashir wields stick to lead Sudan shorn of south. Reuters, April 24

Friedman U (2017) What is a populist? And is Donald Trump one? The Atlantic, February 27

Galston W (2018) The populist challenge to liberal democracy. J Democr 29(2):5-19

Gumede W (2019) The International Criminal Court and accountability in Africa. Africa at LSE: LSE's engagement in Africa. http://blogs.lse.ac.uk/africaatlse/2018/01/31/the-internationalcriminal-court-and-accountability-in-africa/. Accessed 22 Mar 2019

Helfer LR (2018) Populism and international human rights institutions: a survival guide. iCourts Danish National Research Foundation's Centre of Excellence for International Courts Working Paper Series, No. 133. https://papers.ssrn.com/sol3/papers.cfm?abstract_id=3202633. Accessed 22 Mar 2019

Helfer LR, Showalter AE (2017) Opposing International Justice: Kenya's Integrated Backlash Strategy Against the ICC. iCourts Danish National Research Foundation's Centre of Excellence for International Courts Working Paper Series. No. 83 https://scholarship.law.duke.edu/cgi/ viewcontent.cgi?article $=6404 \&$ context=faculty_scholarship. Accessed 22 Mar 2019

Hersher R (2016) Gambia Says it will leave the 'International Caucasian Court'. NPR International, October 26

Hobbs P (2015) Contemporary challenges in relation to the prosecution of senior state officials before the International Criminal Court. Int Crim Law Rev 15(1):76-100

\footnotetext{
${ }^{1}$ I would like to thank the participants of the 2018 AMINTAPHIL conference, and particularly Richard Nunan and Mark Navin, for their helpful comments on this paper.
} 
Jansen RS (2015) Populist mobilization: a new theoretical approach to populism. In: de la Torre C (ed) The promise and perils of populism: global perspectives. University Press of Kentucky, Lexington, pp 159-188

Kagwanja P (2009) Courting genocide: populism, ethno-nationalism and the informalisation of violence in Kenya's 2008 post-election crisis. J Contemp Afr Stud 27(9):365-387

Kuwali D (2018) Africa and the International Criminal Court. In: Nagar D, Mutasa C (eds) Africa and the world: bilaterial and multilateral international diplomacy. Palgrave Macmillan, London, pp 371-401

Laclau E (2005) On populist reason. Verso, London

Laclau E (2012) (reprint ed) Politics and ideology in marxist theory: capitalism, fascism, and populism. Verso, London

Lekalake R, Buchanan-Clarke S (2015) Support for the International Criminal Court in Africa: evidence from Kenya. Afrobarometer. http://afrobarometer.org/publications/pp23-support-inter national-criminal-court-africa-evidence-kenya. Accessed 22 Mar 2019

Maupeu H (2013) Kenyan elections: the ICC, God and the 2013 Kenyan General Elections. Afr Contemp 3(247):33-51

Mavhinga D, Stagno Ugarte B (2017) Where is Zambia's President Heading? Human Rights Watch. https://www.hrw.org/news/2017/07/13/where-zambias-president-heading. Accessed 22 Mar 2019

Mills CW (2008) Racial liberalism. Mod Lang Assoc 123(5):1389-1397

Mills K, Bloomfield A (2017) African resistance to the International Criminal Court: halting the advance of the anti-impunity norm. Rev Int Stud 44(1):101-127

Mudde C (2015a) Some further thoughts on populism. In: de la Torre C (ed) The promise and perils of populism: global perspectives. University Press of Kentucky, Lexington, pp 431-451

Mudde C (2015b) The problem with populism. The Guardian, February 17

Müller J (2016) What is populism? University of Pennsylvania Press, Philadelphia

Ndunda J (2018) Kenya will not withdraw from ICC, says Githu Muigai. The Star, February 27

Norris P, Inglehart R (2019) Cultural backlash: trump, brexit, and authoritarian populism. Cambridge University Press, New York

Odongo D (2018) Kenya committed to ICC, says Githu Muigai. Capital News, February 28

Posner EA (2017) Liberal internationalism and the populist backlash. Chicago Public Law and Legal Theory Working Paper No. 606. https://chicagounbound.uchicago.edu/cgi/viewcontent. cgi?article=2071\&context=public_law_and_legal_theory. Accessed 22 Mar 2019

Resnick D (2015) Varieties of African populism in comparative perspective. In: de la Torre C (ed) The promise and perils of populism: global perspectives. University Press of Kentucky, Lexington, pp 317-348

Resnick D (2017) Populism in Africa. In: Kaltwasser CR, Taggart P, Espejo PO, Ostiguy P (eds) Oxford Handbooks Online. https://www.oxfordhandbooks.com/view/10.1093/oxfordhb/ 9780198803560.001.0001/oxfordhb-9780198803560-e-4. Accessed 5 Sept 2019

Roberts KM (2015) Populism, political mobilizations, and crises of political representation. In: de la Torre C (ed) The promise and perils of populism: global perspectives. University Press of Kentucky, Lexington, pp 140-158

Steinberg RH (2016) Introduction to Part 7. In: Steinberg RH (ed) Contemporary issues facing the International Criminal Court. Brill Nijhoff, Leiden, pp 306-325

Vilmer J-BJ (2016) The African Union and the International Criminal Court: counteracting the crisis. Int Aff 92(6):1319-1342

Voeten E (2019) Populism and backlashes against International Courts. Perspect Polit. https://doi. org/10.1017/S1537592719000975. Accessed 11 Mar 2020 
Renée Nicole Souris Souris is Assistant Professor of Law and Society at the Florida Institute of Technology, where she teaches courses in the Humanities and Pre-Law Programs. Before coming to Florida Tech, she taught for 5 years in the Department of Justice, Law and Criminology in the School of Public Affairs at American University in Washington, DC. Her research examines complex legal and philosophical questions concerning moral development and the criminal responsibility of child soldiers and adult soldiers recruited as children. 